\title{
The quality of the Florisbad spring-water in relation to the quality of the groundwater and the effects of rainfall
}

\author{
RM Douglas \\ National Museum, PO Box 266, Bloemfontein 9300, South Africa
}

\begin{abstract}
The spring-water, groundwater and rainfall were examined as part of a study to determine aspects of the environment in which faunal remains at Florisbad were fossilised. A 1988 analysis of the Florisbad spring and exploration pit-water showed a 27\% higher TDS in the pit-water after a high rainfall period, despite the two being located only $22 \mathrm{~m}$ apart. An extended qualitative water-sampling programme in 1999 confirmed a difference, but in this instance the TDS of the same exploration pit was $49 \%$ lower than that of the spring-water after a low rainfall period. This was contrary to the norm where high recharge usually results in low TDS and low recharge results in high TDS. Results also showed extreme TDS variations of up to 6 times higher between individual pit-waters $54 \mathrm{~m}$ apart. The fluctuation in the quality of the pit-water, in relation to the stable spring-water, led to the conclusion that the two should be separate entities. It was further concluded that the mineralisation of the pit-water originated either directly, or indirectly, from a source other than the spring-water. Long-term rainfall appears to have only a slight effect on the quality of the spring-water and possibly no effect on the quality of the pit-water, while short-term rainfall appears to have little effect on the spring-water quality, but has a decided influence on the pit-waters. Aspects relating to water quality and water monitoring at Florisbad are discussed and a comprehensive historic record of the spring-water quality and composition is also given. Investigations on the origin/s of the groundwater mineralisation are continuing. The results clearly indicate that the spring-water does not currently carry sufficient mineralisation for fossilisation.
\end{abstract}

\section{Introduction}

Florisbad spring is located $49 \mathrm{~km}$ north-west of Bloemfontein and is located on the eastern boundary of the Western Free State panveld. The topography of the area is slightly undulating with occasionally washes from infrequent runoff. The residence at Florisbad is located on the op of a lunette, which has been formed from aeolian sand deposited by the prevailing north-west wind. Drainage is from south to north with a vlei draining to the north from the third swimming pool. The northern tip of the farm incorporates a part of an extensive salt pan, Soutpan.

The $500 \mathrm{~mm}$ isohyet passes slightly to the east of Florisbad with an average 78 year rainfall of $496 \mathrm{~mm}$. Annual rainfall is extremely variable with a maximum of $957 \mathrm{~mm}$ in 1988 and a minimum of $271 \mathrm{~mm}$ in 1965. The flow rates of the spring, as given in the literature, are possibly not very reliable and vary from $18.8 \mathrm{~m}^{3} / \mathrm{h}$ (Grobler and Loock, 1988) to $159.3 \mathrm{~m}^{3} / \mathrm{h}$ (Kent, 1948). It has been suggested that seismic activity has played a role in the flow rate of the spring over time, as well as in the migration of spring eyes. During the September 1912 earthquake at Fauresmith, a new spring eye appeared at Florisbad. Water flow was said to have increased and gas, sand, artefacts and fossils were expelled from the new eye (Anon, 1980)

Loock and Grobler (1988) stated that the basement rocks of the area were of the Ventersdorp Supergroup overlying older granite and gneiss. This basement is in turn overlain by a Permian Age Karoo sequence of the Ecca Group into which dolerite dykes and sills have intruded (Brink, 1987; Loock and Grobler, 1988). It is at such a dolerite intrusion that the Florisbad spring has formed. The surface geology is composed of an unconsolidated mantle of redyellow and pale bleached aeolian sand of varying depth (Brink,

푱(051) 447-9609; fax (051) 447-6273; e-mail: reptile @ nasmus.co.za Received 31 March 2000; accepted in revised form 3 August 2000.
1987; Loock and Grobler, 1988). There is no outcropping of bedrock formations on the farm, while calcrete horizons that have been exposed through erosion, occur in the vlei draining from the spring site.

No specific research has been carried out on the Florisbad spring aquifer and therefore factors such as size, recharge, storage capacity and abstraction are unknown. Grobler and Loock (1988) postulated that the intake of the Florisbad aquifer was located 30 $\mathrm{km}$ north of Florisbad at Basberg where permeable Beaufort sandstone occurred at an elevation of $150 \mathrm{~m}$ above Florisbad. The possibility that the intake area of the spring may lie equidistant to the south-east of Florisbad, in the hills north of Bloemfontein, was also suggested by Grobler and Loock (1988). It was calculated that if the water intake area was located at Basberg, the water would have to descend to the contact zone between the Karoo and the Upper Ventersdorp basement rock at approximately $500 \mathrm{~m}$, in order to reach a temperature of $32^{\circ} \mathrm{C}$ to $33^{\circ} \mathrm{C}$, and issue at $29^{\circ} \mathrm{C}$ (Grobler and Loock, 1988). There, however, appears to be some uncertainty as to the travel time that recharge water could take to travel from the intake area, through the aquifer, to the spring eyes. Grobler and Loock (1988) calculated anything from 160 to 16000 years, with a probable 1600 , years for the water to travel this distance.

With the exception of intermittent spring-water sampling (Rindl, 1915; Fourie, 1970; Mazor and Verhagen, 1983; Douglas, 1992), a study by Grobler and Loock (1988) on the characteristics and genesis of the spring, and some hdydrological data supplied by Fourie (1970), the hydrological environment at Florisbad has been largely ignored. This is perhaps somewhat surprising considering the amount, and diversity, of palaeontological, archaeological, geological, and other research, that has been centred on the spring and its associated fossil remains (Brink, 1987; Douglas, 1992). The association between the spring-water and fossil remains probably originated from reports of fossil finds when the swimming pools 


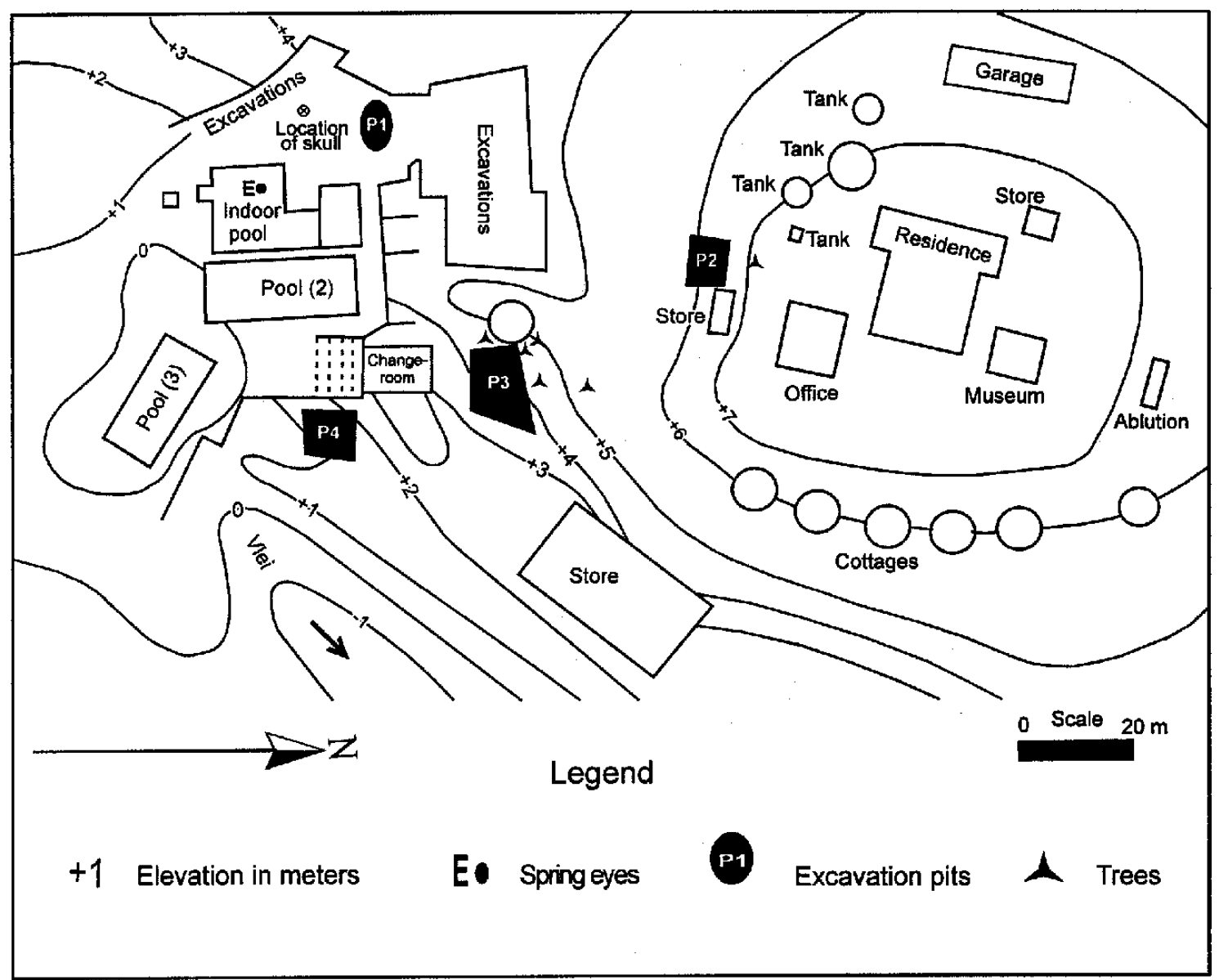

Figure 1

Map of the Florisbad mound showing the water sampling sites

were enlarged in 1912 as well as from fossils expelled during the earthquake of the same year.

In June 1988, various water bodies at Florisbad Research Station were sampled as part of an ecological investigation into the herpetofauna of Florisbad farm (Douglas, 1992). In this study, water quality was examined in terms of saline tolerance, habitat utilisation, and breeding by amphibians (Douglas, 1992). A reexamination of these results showed that the water from one of the exploration pits, located only $22 \mathrm{~m}$ from the spring eyes in the indoor pool, had a 27\% higher total dissolved solids (TDS). It was thought that the TDS of the pit-water could well have been in a diluted state due to a high recharge from one of the highest rainfall periods recorded. Similarly, during drier periods, the TDS could be increased further by evaporation.

Brouwer (1967) noted that many detailed palaeontological descriptions make no mention at all of the conditions under which the fossilisation has taken place. The purpose of this study was to establish a basis for an ongoing study to determine aspects of the environment in which faunal remains at Florisbad were fossilised and the relationship and effects of that environment on fossilisation. It was felt that further investigations were warranted in order to investigate statements by Brink $(1987 ; 1988)$ that the slightly alkaline nature of the spring-water was the reason for the good faunal preservation; that the chemical nature of the spring-water had caused remains to be preserved in a characteristic way; and that faunal remains of the Old Collection had became fossilised in contact with the spring water. Some of the other objectives of this preliminary qualitative investigation were to confirm, or refute, the difference between the Douglas (1992) spring and pit-water TDS; to obtain more information on the quality of the pit-waters and to examine a number of factors which may have had an influence on the pit-water values. Yet another important aspect was to provide a background for further investigations into the mineralisation of the pit-waters. As sampling took place over both wet and dry periods some aspects of the possible effect of rainfall could also be examined. Because only sporadic interest has been shown in the spring-water quality over the years it was considered important to add the results of Douglas (1992) (unpublished), and this study, to the published historic record of spring-water quality, as well as to collate some of the existing hydrological information.

\section{Sampling and water quality results}

In August 1999 samples of the spring-water (E99) as well as the water in the four exploration pits (P199, P299, P399, P499) were analysed. The locations of the sample sites are given in Fig. 1, where "E" represents the spring eyes in the indoor bathhouse and "P" represents the exploration pits. The year in which the two sets of samples were taken is represented by either " 88 " or " 99 ". All water samples, including E88 and P188, were analysed by the Institute for Groundwater Studies, University of the Orange Free State, Bloemfontein. In Tables 2 and 3, only factors and ions common to both the 1988 and 1999 analyses have been used in the compilations. 
Rainfall figures for the period January 1922 to September 1999 were recorded at either the Florisbad Weather Station or Florisbad Research Station. Missing data was taken from Glen Agricultural College Weather Station records, 32 $\mathrm{km}$ east of Florisbad. To illustrate the variation in the occurrence of ions between the spring- and pit-water, the relative ion increases and decreases between the eye and $\mathrm{P} 1$, and between the pits, were plotted (Fig. 2). The possible influence of longterm rainfall on the ion concentrations of the springand pit-waters were examined from annual rainfall figures plotted for the ten-year period prior to the 1999 and 1988 sampling periods (Fig. 3). Average three-monthly rainfall was also plotted for the 24 months prior to each of the aforementioned sampling periods in order to determine the possible effects of shortterm rainfall (Fig. 4). Annual rainfall for the year prior to the 1999 and 1988 sampling periods was then plotted against the total anion and cation concentrations for both the spring- and pit-water (Fig. 5).The 1999 spring-water temperature was taken at a depth of $2.2 \mathrm{~m}$ inside one of the eye vent pipes in the indoor pool. Temperatures were also taken at various depths and locations in the indoor pool itself and it was found that the temperature in the indoor pool was $0.9^{\circ} \mathrm{C}$ to $1.2^{\circ} \mathrm{C}$ lower than in the vent pipes. However, this range may not be as great in mid-summer when the ambient air temperature is higher.

\section{Results}

The 1999 spring (E99) and pit-water results (P199, P299, P399, P499) are presented in Table 1 and shows the differences in quality between the spring and the pit-water, as well as the difference in water quality between the various pits. The TDS of P199 was 49\% lower than E99 while the TDS of P299 was 22\% lower than E99. However, TDS increased by $94 \%$ for P399, and $287 \%$ for P499, as compared to E99. There was also a TDS increase between P199 and P299 of 55\%, between P199 and P399 of 283\%, and between P199 and $\mathrm{P} 499$ of $666 \%$. Of interest was that the increase in the
TABLE 1

Results of the 1999 Florisbad spring and groundwater analyses

\begin{tabular}{|c|c|c|c|c|c|}
\hline & E99 & P199 & P299 & P399 & P499 \\
\hline $\begin{array}{l}\mathrm{pH} \\
\mathrm{p}-\mathrm{Alk} \\
\mathrm{m}-\mathrm{Alk} \\
\mathrm{EC}(\mathrm{mS} / \mathrm{m}) \\
\text { Salinity*(\%) } \\
\mathrm{NaCl}^{* *}(\%) \\
\text { Scintillation (CPS) }\end{array}$ & $\begin{array}{r}8.91 \\
7.00 \\
12.00 \\
388.00 \\
6.36 \\
7.55 \\
10-14\end{array}$ & $\begin{array}{r}7.88 \\
0.00 \\
171.00 \\
220.00 \\
3.04 \\
3.61 \\
9-12\end{array}$ & $\begin{array}{r}7.65 \\
0.00 \\
138.00 \\
325.00 \\
4.71 \\
5.59 \\
14-17\end{array}$ & $\begin{array}{r}7.66 \\
0.00 \\
116.00 \\
750.00 \\
12.13 \\
14.39 \\
12-14\end{array}$ & $\begin{array}{r}8.14 \\
0.00 \\
92.00 \\
1419.00 \\
24.48 \\
29.04 \\
15-18\end{array}$ \\
\hline $\begin{array}{l}\text { ANIONS (mg/l) } \\
\text { Chloride } \\
\text { Nitrite } \\
\text { Bromide } \\
\text { Nitrate } \\
\text { Phosphate } \\
\text { Sulphate } \\
\text { Fluoride } \\
\text { Silica }\end{array}$ & $\begin{array}{r}1442.000 \\
0.010 \\
19.306 \\
0.733 \\
1.929 \\
1.500 \\
5.500 \\
6.570\end{array}$ & $\begin{array}{r}685.000 \\
0.010 \\
8.462 \\
1.186 \\
0.100 \\
2.600 \\
9.950 \\
7.790\end{array}$ & $\begin{array}{r}1104.000 \\
0.010 \\
15.855 \\
0.901 \\
0.010 \\
6.600 \\
6.030 \\
8.240\end{array}$ & $\begin{array}{r}2824.000 \\
0.010 \\
36.014 \\
2.335 \\
0.010 \\
2.700 \\
5.260 \\
10.700\end{array}$ & $\begin{array}{r}5648.000 \\
0.010 \\
71.964 \\
4.807 \\
0.010 \\
81.600 \\
10.410 \\
0.000\end{array}$ \\
\hline $\begin{array}{l}\mathrm{CATIONS}(\mathrm{mg} / \mathrm{l}) \\
\mathrm{Ca} \text {. } \\
\mathrm{Mg} \\
\mathrm{Na} \\
\mathrm{K} \\
\mathrm{Al} \\
\mathrm{Fe} \\
\mathrm{Mn} \\
\mathrm{Cr} \\
\mathrm{Zn} \\
\mathrm{Cu} \\
\mathrm{Cd} \\
\mathrm{B} \\
\mathrm{Sr} \\
\mathrm{Co} \\
\mathrm{As} \\
\mathrm{La} \\
\mathrm{Be} \\
\mathrm{Se} \\
\mathrm{Li} \\
\mathrm{Ba} \\
\mathrm{Ni} \\
\mathrm{Mo} \\
\mathrm{V} \\
\mathrm{Ag}\end{array}$ & $\begin{array}{r}100.000 \\
0.440 \\
784.000 \\
10.100 \\
0.054 \\
0.014 \\
0.003 \\
<0.010 \\
0.016 \\
0.004 \\
<0.006 \\
2.588 \\
2.790 \\
<0.003 \\
<0.015 \\
<0.050 \\
<0.010 \\
<0.020 \\
0.347 \\
0.126 \\
<0.006 \\
0.002 \\
<0.025 \\
<0.010\end{array}$ & $\begin{array}{r}82.000 \\
3.910 \\
380.000 \\
8.620 \\
0.139 \\
0.106 \\
0.021 \\
<0.010 \\
0.026 \\
0.008 \\
<0.006 \\
1.735 \\
1.890 \\
<0.003 \\
<0.015 \\
<0.050 \\
<0.010 \\
<0.020 \\
0.451 \\
0.090 \\
<0.006 \\
0.009 \\
0.026 \\
<0.010\end{array}$ & $\begin{array}{r}136.000 \\
5.150 \\
554.000 \\
12.900 \\
0.076 \\
0.152 \\
0.788 \\
<0.010 \\
0.030 \\
0.014 \\
<0.006 \\
2.003 \\
2.950 \\
<0.003 \\
<0.015 \\
<0.050 \\
<0.010 \\
<0.020 \\
0.272 \\
0.167 \\
0.016 \\
0.004 \\
0.030 \\
<0.010\end{array}$ & $\begin{array}{r}257.000 \\
7.510 \\
1420.000 \\
28.200 \\
0.038 \\
0.058 \\
0.464 \\
<0.010 \\
0.040 \\
0.017 \\
<0.006 \\
6.414 \\
6.380 \\
<0.003 \\
<0.015 \\
<0.050 \\
<0.010 \\
<0.020 \\
0.787 \\
0.548 \\
0.018 \\
0.003 \\
0.043 \\
<0.010\end{array}$ & $\begin{array}{r}400.000 \\
9.040 \\
2920.000 \\
42.540 \\
0.041 \\
0.033 \\
0.016 \\
<0.010 \\
0.034 \\
0.017 \\
<0.006 \\
10.158 \\
11.200 \\
<0.003 \\
<0.015 \\
<0.050 \\
<0.010 \\
<0.020 \\
2.310 \\
0.468 \\
0.020 \\
0.012 \\
0.058 \\
<0.010\end{array}$ \\
\hline Total ions & 2383.867 & 1204.209 & 1862.352 & 4613.933 & 9223.282 \\
\hline
\end{tabular}

groundwater TDS between P299, P399 and P499 was almost lineal in a west to east direction. Factors possibly influencing these values are discussed further on. These variations in groundwater, in relation to the relatively stable spring-water, would strongly suggest that the pit-waters are not directly related to the spring-water and that the spring- and pit-water could be seen as separate entities.

The most notable ion increase between P199 and P499 was that of $\mathrm{SO}_{4}$, which showed a 30 -fold increase. Other noteworthy increases were $\mathrm{Br} 750 \%, \mathrm{Cl} 725 \%$, salinity $705 \%$, Na 668\%, EC $545 \%, \mathrm{Sr} 494 \%$, B $485 \%$, Ba 420\%, Li 412\%, and Ca $387 \%$.

Table 2 gives the comparative results between the spring-water E99 and E88, and the pit-water P199 and P188. In order to accentuate any quality changes, the percentage increase, or decrease, of ions and other factors is also given. From the TDS it was clear 


\begin{tabular}{|c|c|c|c|c|c|c|}
\hline \multicolumn{7}{|c|}{$\begin{array}{c}\text { TABLE } 2 \\
\text { Variations in water quality between the Florisbad spring-water (E99 and E88) and } \\
\text { pit } 1 \text { groundwater (P199 and P188) over a ten-year period }\end{array}$} \\
\hline & E99 & E88 & $\begin{array}{r}\% \text { Inc/ } \\
\text { Dec }\end{array}$ & P199 & P188 & $\begin{array}{r}\% \text { Inc/ } \\
\text { Dec }\end{array}$ \\
\hline $\begin{array}{l}\mathrm{pH} \\
\text { p-Alk } \\
\mathrm{m}-\mathrm{Alk} \\
\text { EC } \\
\text { Salinity*(\%) } \\
\mathrm{NaCl}^{* *}(\%)\end{array}$ & $\begin{array}{r}8.91 \\
7.00 \\
12.00 \\
388.00 \\
6.36 \\
7.55\end{array}$ & $\begin{array}{r}9.34 \\
11.25 \\
23.72 \\
398.00 \\
5.96 \\
7.07\end{array}$ & $\begin{array}{r}-5 \\
-38 \\
-49 \\
-3 \\
+7 \\
+7\end{array}$ & $\begin{array}{r}7.88 \\
0.00 \\
171.00 \\
220.00 \\
3.04 \\
3.61\end{array}$ & $\begin{array}{r}7.01 \\
- \\
119.46 \\
493.00 \\
7.34 \\
8.73\end{array}$ & $\begin{array}{r}+12 \\
- \\
+43 \\
-55 \\
-59 \\
-59\end{array}$ \\
\hline $\begin{array}{l}\text { ANIONS }(\mathrm{mg} / \mathrm{l}) \\
\text { Chloride } \\
\text { Nitrite } \\
\text { Bromide } \\
\text { Nitrate } \\
\text { Phosphate } \\
\text { Sulphate }\end{array}$ & $\begin{array}{r}1442.000 \\
0.010 \\
19.306 \\
0.733 \\
1.929 \\
1.500\end{array}$ & $\begin{array}{r}1361.32 \\
0.00 \\
4.34 \\
0.24 \\
0.00 \\
1.55\end{array}$ & $\begin{array}{r}+6 \\
+1000 \\
+345 \\
+205 \\
+192993 \\
-3\end{array}$ & $\begin{array}{r}685.000 \\
0.010 \\
8.462 \\
1.186 \\
0.100 \\
2.600\end{array}$ & $\begin{array}{r}1670.81 \\
0.00 \\
5.05 \\
0.44 \\
0.51 \\
24.41\end{array}$ & $\begin{array}{r}-59 \\
+1000 \\
+68 \\
+170 \\
-80 \\
-89\end{array}$ \\
\hline $\begin{array}{l}\mathrm{CATIONS}(\mathrm{mg} / \mathrm{l}) \\
\mathrm{Ca} . \\
\mathrm{Mg} \\
\mathrm{Na} \\
\mathrm{K} \\
\mathrm{Al} \\
\mathrm{Fe} \\
\mathrm{Mn} \\
\mathrm{Cr} \\
\mathrm{Zn} \\
\mathrm{Cu} \\
\mathrm{Cd} \\
\mathrm{B}\end{array}$ & $\begin{array}{r}100.000 \\
0.440 \\
784.000 \\
10.100 \\
0.054 \\
0.014 \\
0.003 \\
0.010 \\
0.016 \\
0.004 \\
0.006 \\
2.588\end{array}$ & $\begin{array}{r}98.360 \\
0.502 \\
725.060 \\
9.110 \\
0.150 \\
0.215 \\
0.012 \\
0.124 \\
0.181 \\
0.059 \\
0.061 \\
1.620\end{array}$ & $\begin{array}{r}+2 \\
-12 \\
+8 \\
+11 \\
-64 \\
-93 \\
-75 \\
-92 \\
-91 \\
-93 \\
-90 \\
+60\end{array}$ & $\begin{array}{r}82.000 \\
3.910 \\
380.000 \\
8.620 \\
0.139 \\
0.106 \\
0.021 \\
0.010 \\
0.026 \\
0.008 \\
0.006 \\
1.735\end{array}$ & $\begin{array}{r}168.570 \\
5.736 \\
903.330 \\
12.460 \\
0.150 \\
3.999 \\
1.141 \\
0.114 \\
0.178 \\
0.065 \\
0.050 \\
1.807\end{array}$ & $\begin{array}{r}-51 \\
-32 \\
-58 \\
-31 \\
-7 \\
-97 \\
-98 \\
-91 \\
-85 \\
-88 \\
-88 \\
-4\end{array}$ \\
\hline Total ions & 2362.713 & 2202.904 & +7 & 1173.939 & 2798.820 & -58 \\
\hline
\end{tabular}

concentrations relative to the previous sample. With the exception of the slight jump in ions with increased concentrations between E99-P199 and P199-P299, other increases remained constant in a west to east direction. Although there was a $50 \%$ decrease in TDS between E99 and P199, $41 \%$ of P199ions had higher concentrations than E99. In most instances these increases were not confined to specific ions and the increases varied between ions and samples. This indicates that TDS does not always give a true picture of water quality, particularly when minor salts are involved.

Average rainfall over the 78 -year period was $496 \mathrm{~mm}$, with a maximum annual rainfall of $957 \mathrm{~mm}$ in 1988 and a minimum of $271 \mathrm{~mm}$ in 1965. Even over this short time span, extremes in wet and dry periods are apparent at Florisbad. Annual rainfall for the ten-year period prior to the 1999 and 1988 sampling is presented in Fig. 3. Despite a high of 957 $\mathrm{mm}$ being recorded within the 1988 ten-year period, the pre ten-year average was

that the spring-water remained relatively stable between 1988 and 1999 , with only a $7 \%$ increase in ions. Table 2 also confirmed the variability of the pit-water quality, not only over a period of time, but also at the same site, with P1 showing a 58\% decrease in ions between 1988 and 1999. Notable from both Tables 1 and 2 was that while the calcium level in the spring-water remained constant at about $100 \mathrm{mg} / \mathrm{l}$, there was a considerable fluctuation of calcium in the pit-water, with P188 being 106\% higher than P199. Although some ions showed considerable increases and decreases, these were often from a very low base.

The comparative results between the spring-water E99 and the pit-water P199, and between the spring-water E88 and the pit-water P188, are presented in Table 3. Of particular interest is that not only does Table 3 show the differences between the spring and pit-water quality, but also the fluctuation of pit-water ions either side of the relatively stable spring-water. Contrary to the $27 \%$ higher TDS of P188 over E88, the TDS of P199 was $49 \%$ lower than E99. Sulphate, magnesium, iron and manganese values were also considerably higher in P188 relative to both E88 and P199. This supported the theory that if the pit-water was directly related to the spring-water, then there should have been a greater parity between the two.

Figure 2 gives the relative number of ions with increased and decreased concentrations between E99 and P199, P199 and P299, P299 and P399 and P399 and P499. In conjunction with Table 1, it will be noted that between $41 \%$ and $53 \%$ of ions increased their
$459 \mathrm{~mm}$, while the pre- 1999 ten-year average was $515 \mathrm{~mm}$, or $12 \%$ higher. This higher rainfall corresponded to a $7 \%$ increase in ions between E88 and E99. Although this might be indicative of a possible longer-term rainfall effect on the spring-water, it may not necessarily reflect periods of high rainfall within the ten-year periods examined. It may on the other hand reflect influences over even longer or shorter periods, depending on factors such as the size and recharge area of the aquifer, which are not known. Contrary to this increase, the ion levels between P188 and P199 decreased by $58 \%$ over the same period, possibly indicating that longer term rainfall had no effect on ion concentrations in the pit-waters.

Rainfall for the 24 months preceding the 1999 and 1988 sampling was plotted as three-month averages (Fig. 4) and the results found to be contrary to those obtained over the ten-year periods. The 198824 -month average rainfall was $35 \%$ higher than the 1999 period, while the 1988 12-, 9-, 6-, and 3-month averages were $73 \%, 93 \%, 433 \%$ and $2150 \%$ higher, respectively, than for the corresponding 1999 periods. In order to illustrate the effect, and relationship, between rainfall and ion concentrations, the 1988 and 1999 annual rainfall figures were plotted against total ions for E88 and P188, and E99 and E199 (Fig. 5). Figure 5 shows that the 42\% decrease in annual rainfall between 1988 and 1999 had very little influence on the TDS of the spring-water, with only a slight converse 7\% increase in ions between E88 and E99 (see also Table 2 ). Results also showed that the $73 \%$ increase in rainfall between 1999 and 1988 corresponded to a $138 \%$ ion increase in P1. 
Conversely, the $42 \%$ decrease in rainfall between 1988 and 1999 corresponded to a $58 \%$ decrease in ions in P1. This would tend to indicate that the short-term rainfall has a far greater influence on the pit-water ions than long-term rainfall.

The intermittent Florisbad spring-water analyses (Rindl, 1915; Fourie, 1970; Mazor and Verhagen, 1983; Douglas, 1992) over the past 84 years are presented in Table 4 and provide a modern historic account of the spring-water composition and quality. Under Rindl (1915), methane, hydrogen and nitrogen results have been incorporated from Rindl (1916). As previous researchers have examined different aspects of the spring-water, the compilation in Table 4 gives a far broader and more detailed picture of the spring-water composition and quality than would be obtained from the specific studies. The mineral analysis of the sand by Fourie (1970) has been included because some minerals not included in the various water analyses in the sands, and conversely, some minerals in the water analyses were found in the sands. This then also provides a more comprehensive record of the mineralisation of the spring site.

In relation to the fossilisation of faunal remains it is apparent at this stage of the investigation that there is insufficient mineralisation in the spring-water, particularly $\mathrm{Ca}, \mathrm{CaCO}_{3}$ and $\mathrm{Si}$ (Table 4), for fossilisation. However, on the other hand it would appear that the groundwater may well carry sufficient $\mathrm{CaCO}_{3}$ for this process. This aspect, and the possibility of the spring-water having a historically low mineral content, is being investigated further.

\section{Discussion}

Flow rates of the spring given in the literature appear to be inconsistent, irregular and the reliability of the data uncertain. This is due to one or more of the following factors: not being able to ascertain when or where the measurement was taken; the sampling method not being mentioned; and the use of different sampling methods. Although the flow rate of $112.5 \mathrm{~m}^{3} / \mathrm{h}$ given by Rindl (1915) was not actually taken by him, and no mention was made from where he obtained this figure, he thought this figure to be exaggerated. The $49.4 \mathrm{~m}^{3} / \mathrm{h}$ to $55.9 \mathrm{~m}^{3} / \mathrm{h}$ flow rate given by Fourie (1970) was determined from what is presumed to be two of the three pools, although it is indicated on his map that the sampling site was at the outlet of the third pool. Grobler and Loock (1988) state that,
TABLE 3 wariations in water quality between the 1999 Florisbad spring-water (E99) and pit 1 ground-
water (P199), and between the 1998 spring-water (E88) and pit 1 groundwater (P188)

\begin{tabular}{|c|c|c|c|c|c|c|}
\hline & E99 & P199 & $\begin{array}{r}\% \text { Inc/ } \\
\text { Dec }\end{array}$ & E88 & P188 & $\begin{array}{r}\% \text { Inc/ } \\
\text { Dec }\end{array}$ \\
\hline $\mathrm{pH}$ & 8.91 & 7.88 & -12 & 9.34 & 7.01 & -33 \\
\hline p-Alk & 7.00 & 0.00 & -100 & 11.25 & - & - \\
\hline m-Alk & 12.00 & 171.00 & +1325 & 23.72 & 119.46 & +404 \\
\hline EC & 388.00 & 220.00 & -43 & 398.00 & 493.00 & +24 \\
\hline Salinity*(\%) & 6.36 & 3.04 & -52 & -5.96 & 7.34 & +23 \\
\hline $\mathrm{NaCl}^{* *}(\%)$ & 7.55 & 3.61 & -52 & 7.07 & 8.73 & +23 \\
\hline ANIONS (mg/l) & & & & & & \\
\hline Chloride & 1442.000 & 685.000 & -52 & 1361.32 & 1670.81 & +23 \\
\hline Nitrite $\left(\mathrm{NO}_{2}\right)$ & 0.010 & 0.010 & 0 & 0.00 & 0.00 & 0 \\
\hline Bromide & 19.306 & 8.462 & -56 & 4.34 & 5.05 & +16 \\
\hline Nitrate & 0.733 & 1.186 & +62 & 0.24 & 0.44 & +83 \\
\hline Phosphate & 1.929 & 0.100 & -95 & 0.00 & 0.51 & +5100 \\
\hline Sulphate & 1.500 & 2.600 & +73 & 1.55 & 24.41 & +1475 \\
\hline CATIONS (mg/l) & & & & & & \\
\hline $\mathrm{Ca}$ & 100.000 & 82.000 & -18 & 98.360 & 168.570 & +71 \\
\hline $\mathrm{Mg}$ & 0.440 & 3.910 & +789 & 0.502 & 5.736 & +1043 \\
\hline $\mathrm{Na}$ & 784.000 & 380.000 & -52 & 725.060 & 903.330 & +25 \\
\hline $\mathrm{K}$ & 10.100 & 8.620 & -15 & 9.110 & 12.460 & +37 \\
\hline $\mathrm{Al}$ & 0.054 & 0.139 & +157 & 0.150 & 0.150 & 0 \\
\hline $\mathrm{Fe}$ & 0.014 & 0.106 & +675 & 0.215 & 3.999 & +1760 \\
\hline Mn & 0.003 & 0.021 & +600 & 0.012 & 1.141 & +9408 \\
\hline $\mathrm{Cr}$ & 0.010 & 0.010 & 0 & 0.124 & 0.114 & -8 \\
\hline $\mathrm{Zn}$ & 0.016 & 0.026 & +63 & 0.181 & 0.178 & -2 \\
\hline $\mathrm{Cu}$ & 0.004 & 0.008 & +100 & 0.059 & 0.065 & +10 \\
\hline $\mathrm{Cd}$ & 0.006 & 0.006 & 0 & 0.061 & 0.050 & -18 \\
\hline B & 2.588 & 1.735 & -33 & 1.620 & 1.807 & +12 \\
\hline Total ions & 2362.713 & 1173.939 & -50 & 2202.904 & 2798.820 & +27 \\
\hline
\end{tabular}

based on unpublished data with no mention of who took the measurements or how the measurements were taken, the flow rate increased from $4.5 \mathrm{~m}^{3} / \mathrm{h}$ to $18.8 \mathrm{~m}^{3} / \mathrm{h}$ after the 1912 eruption of the new spring eye. Kent (1948) gives the highest flow rate of $159.3 \mathrm{~m}^{3} /$ $\mathrm{h}$, but again with no details.

As the monitoring of spring flow and groundwater levels are important for estimating recharge, if the recharge area were known, the most practical site for monitoring both these factors at Florisbad would be the overflow, or discharge, from the third swimming pool. The three pools at Florisbad are interconnected with the accumulated water discharging from the top of the third pool into the vlei to the north. Douglas (1992) noted that there were minor differences in ion concentrations between the indoor pool and pool 3 , with a $1.5 \%$ TDS increase between the two. The water in pool 3 therefore represents the average accumulation of spring-water from approximately 21 eyes of various sizes, and it may be more correct to use the water from this pool for analysis and flow rates, rather than water from the indoor pool. While Bredenkamp (2000) stated that spring flow corresponded surprisingly well to average rainfall over several years prior to a specific month, the term several years would be relative and dependant on factors relating to intake rainfall, size of the aquifer, abstraction and flow rate, none of which are known for Florisbad. Because there have been no studies, or monitoring of the hydrological environment at Florisbad, the majority of parameters given by Bredenkamp (2000) for effective groundwater monitoring such as, hydrological modelling, ground- 


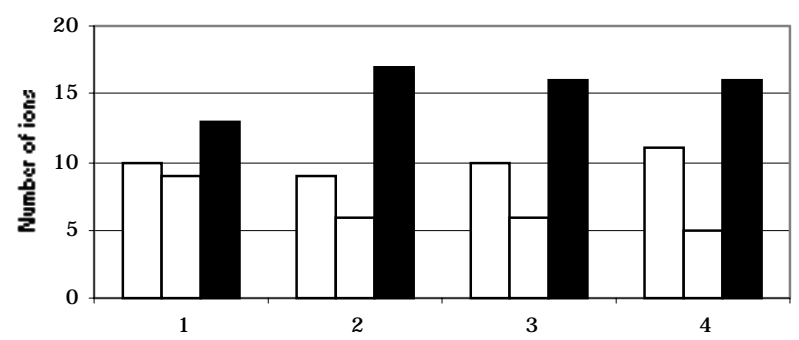

E99-P199 (1), P199-P299 (2), P299-P399 (3), P399-P499 (4)

$\square$ No change $\square$ Decrease $\boldsymbol{\square}$ Increase

Figure 2

The relative number of ions with increased and decreased concentrations between E99 and P199, P199 and P299, P299 and P399, and P399 and P499

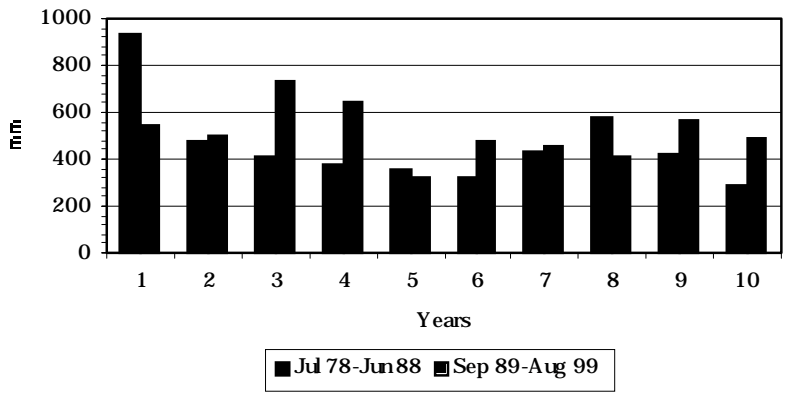

Figure 3

Ten-year average rainfall for Florisbad prior to the June 1988 and August 1999 water sampling

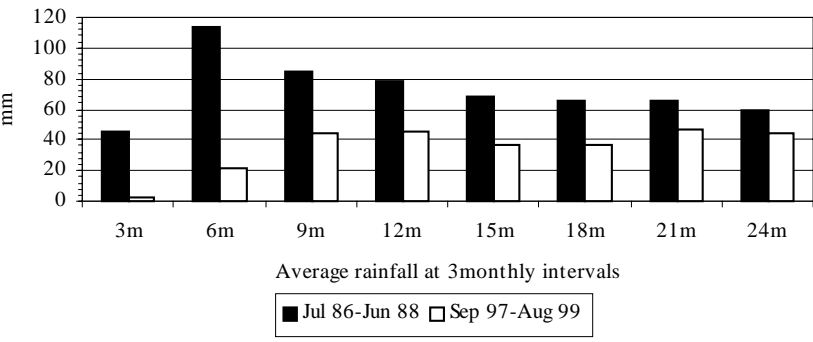

Figure 4

Average three-monthly rainfall for Florisbad for the 24 months prior to the June 1988 and August 1999 water sampling

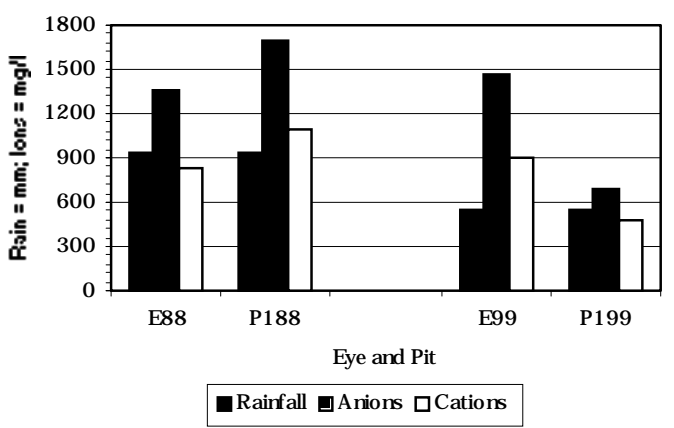

Figure 5

Annual June 1988 and August 1999 rainfall for Florisbad in relation to the anion and cation concentrations of the spring- $(E)$ and pit-water (P1) water recharge and groundwater management, do not exist. This leaves considerable scope for further research.

Numerous interpretations have been put forward relating to the stratigraphy, sedimentology and formation of the Florisbad mound (Fourie, 1970; Rubidge and Brink, 1985). These interpretations have ranged from the sands having largely originated from the spring (Dreyer, 1938; Brink, 1987; Butzer, 1988), to deposition as a result of sedimentation in a flood plain environment (Butzer, 1984; Visser and Joubert, 1991; Joubert and Visser, 1991), to deposition as a result of largely aeolian processes (Grobler and Loock, 1988; Kuman et al., 1999). In the final analysis it will be found that all these factors will have contributed in some way or another to the formation of the mound. From the above interpretations it is clear that there are very few extensive homogeneous strata, while there are many smaller lens-type layers (Butzer, 1984; 1988; Rubidge and Brink, 1985; Brink, 1987). This interrupted stratification would greatly assist in the percolation of recharge water.

The chemical data of groundwater samples reflect the hydrological interactions that occur from the time of recharge to the time of sampling (Bredenkamp, 2000). Groundwater chemistry is also determined firstly by rainfall and secondly by geochemical interactions that occur firstly in the unsaturated zone as the water filtrates down to groundwater level, and secondly, in the saturated aquifer matrix, and thirdly, when pollutants enter the aquifer (Bredenkamp, 2000). In relation to the Florisbad groundwater, recharge rainfall would gather some salts from the largely aeolian sand layers, which are partly derived from the deflation of Soutpan to the north-west, as well as salts deposited by capillarity at or near the surface. It is not, however, thought that the contribution of these salts could account for the high TDS of the groundwater.

The contribution of minerals from the Ecca shale and dolerite, on which the Florisbad mound and groundwater lies, should also be considered. Dolerite, being largely silicate based, is composed largely of plagioclase, feldspar and a ferromagnesian silicate mineral such as biotite, hornblende, pyroxine or chrysolite (Ford, 1966). Some small mineral contribution may have been made by the dolerite in the form of $\mathrm{K}, \mathrm{Fe}, \mathrm{Mn}, \mathrm{Mg}$ and $\mathrm{Ca}$, but this would probably be at low levels. Kent (1949) felt that the high $\mathrm{NaCl}$ of the spring-water was more related to the water having percolating down through the underlying Dwyka series, rather than the overlying Ecca series. Any such contribution would have taken place in an environment where the spring-water had been heated to between $32^{\circ} \mathrm{C}$ and $35^{\circ} \mathrm{C}$, as well as possibly having been in contact with the $\mathrm{Ecca} / \mathrm{Dwyka}$ series for hundreds of years. Over this time span, and under these conditions, the spring-water has still not managed to attain concentration levels near to those of many of the groundwater samples. As the groundwater environment at Florisbad is far cooler, and is also regularly recharged by rainfall, it is felt that diagenesis of the underlying Ecca shale possibly contributes very little to the groundwater concentrations. Should Kent (1949) be correct about the $\mathrm{NaCl}$ contribution arising in the Dwyka series, then the mineral contribution to the groundwater by the underlying Ecca shale could be minimal, suggesting some other source.

The determination of recharge using the $\mathrm{Cl}$ ratio method has been described by Bredenkamp (2000). Bredenkamp (2000) specified that this method was dependant on the $\mathrm{Cl}$ concentrations of rainfall that were sampled in the area being accurately determined, and that no $\mathrm{Cl}$ had been added to the water by dissolution of aquifer material, and that no pollution has occurred. The application of this method may be problematic in the Florisbad context, whether it is being applied to the spring-water or the groundwater. At Florisbad there are no $\mathrm{Cl}$ values available for rainfall, and because of the high spring $\mathrm{Cl}$ values derived from the aquifer material, and the even 


\begin{tabular}{|c|c|c|c|c|c|c|}
\hline \multicolumn{7}{|c|}{$\begin{array}{l}\text { TABLE } 4 \\
\begin{array}{l}\text { The composition and variation of the Florisbad spring-water over an } 84 \text { year period, including } \\
\text { minerals identified in the sands }\end{array}\end{array}$} \\
\hline & RD-1999 & RD-1988 & $\begin{array}{r}\text { M\&V- } \\
1983\end{array}$ & $\begin{array}{r}\text { GP-1970 } \\
\text { Water }\end{array}$ & MR-1915 & $\begin{array}{r}\text { GP-1970 } \\
\text { Sand }\end{array}$ \\
\hline $\mathrm{pH}$ & 8.91 & 9.43 & - & 8.30 & - & - \\
\hline P-Alk & 7.00 & 11.25 & - & - & - & - \\
\hline M-Alk & 12.00 & 23.72 & - & - & 18.69 & - \\
\hline Alkalinity & - & - & 41.00 & - & - & - \\
\hline $\mathrm{EC}(\mathrm{mS} / \mathrm{m})$ & 388.00 & 398.00 & - & - & - & - \\
\hline Salinity $(\%)^{*}$ & 6.36 & 5.96 & 6.14 & 6.00 & 5.80 & - \\
\hline $\mathrm{NaCl}(\%) * *$ & 7.55 & 7.07 & 7.29 & 7.12 & 6.90 & - \\
\hline Hardness - temp. $\left(\mathrm{CaCO}_{3}\right)$ & - & - & - & 177 & - & - \\
\hline Hardness - perm. $\left(\mathrm{CaCO}_{3}\right)$ & - & - & - & 40 & - & - \\
\hline Absorption $\mathrm{O} 2\left(4 \mathrm{~h}\right.$ at $\left.27^{\circ} \mathrm{C}\right)$ & - & - & - & 0.08 & - & - \\
\hline Temperature $\left({ }^{\circ} \mathrm{C}\right)$ & 29.00 & - & 29.00 & 28.88 & 29.05 & - \\
\hline Density & & - & - & - & 1.0015 & - \\
\hline Scintillation (CPS) & $10-14$ & - & - & - & - & - \\
\hline \multicolumn{7}{|l|}{ ANIONS (mg/l) } \\
\hline Chloride & 1442.000 & 1361.32 & 1350.00 & 1321.00 & 1304.578 & - \\
\hline Nitrite & 0.010 & 0.00 & - & 0.00 & - & - \\
\hline Bromide & 19.306 & 4.34 & - & - & - & - \\
\hline Nitrate & 0.733 & 0.24 & - & 0.00 & 0.380 & - \\
\hline Phosphate & 1.929 & 0.00 & - & 0.00 & Trace & - \\
\hline Sulphate & 1.500 & 1.55 & 65.00 & 16.00 & 2.282 & - \\
\hline Fluoride & 5.500 & - & - & 6.00 & - & - \\
\hline Iodine & - & - & 41.00 & 0.25 & Trace & - \\
\hline Carbon & - & - & - & 0.00 & - & $\otimes$ \\
\hline Bicarbonate & - & - & - & 49.00 & 18.690 & a \\
\hline Silica & 6.570 & - & - & - & 21.858 & $\otimes$ \\
\hline \multicolumn{7}{|l|}{ CATIONS (mg/l) } \\
\hline $\mathrm{Ca}$ & 100.000 & 98.360 & 93.00 & 87.00 & 93.424 & $\otimes$ \\
\hline $\mathrm{Mg}$ & 0.440 & 0.502 & 7.00 & 0.00 & 0.794 & $\otimes$ \\
\hline $\mathrm{Na}$ & 784.000 & 725.060 & 800.00 & 778.00 & 744.047 & $\otimes$ \\
\hline $\mathrm{K}$ & 10.100 & 9.110 & 8.00 & 8.00 & - & $\otimes$ \\
\hline $\mathrm{Al}$ & 0.054 & $<0.150$ & - & 7.00 & 0.854 & $\otimes$ \\
\hline $\mathrm{Fe}$ & 0.014 & 0.215 & - & 2.00 & 0.334 & $\otimes$ \\
\hline $\mathrm{Mn}$ & 0.003 & 0.012 & - & 0.00 & - & $\otimes$ \\
\hline $\mathrm{Cr}$ & $<0.010$ & 0.124 & - & - & - & - \\
\hline $\mathrm{Zn}$ & 0.016 & 0.181 & - & - & - & $\otimes$ \\
\hline $\mathrm{Cu}$ & 0.004 & 0.057 & - & 0.00 & - & - \\
\hline $\mathrm{Cd}$ & 0.006 & 0.061 & - & - & - & $\theta$ \\
\hline B & 2.588 & 1.620 & - & - & - & - \\
\hline $\mathrm{Ba}$ & 0.126 & - & - & - & 0.737 & $\otimes$ \\
\hline $\mathrm{Li}$ & 0.347 & - & - & - & 0.693 & $\theta$ \\
\hline Co & $<0.003$ & - & - & - & - & $\theta$ \\
\hline As & $<0.015$ & - & - & - & - & $\theta$ \\
\hline $\mathrm{La}$ & $<0.050$ & - & - & - & - & - \\
\hline $\mathrm{Be}$ & $<0.010$ & - & - & - & - & $\theta$ \\
\hline $\mathrm{Se}$ & $<0.020$ & - & - & - & - & - \\
\hline $\mathrm{Sr}$ & 2.790 & - & - & - & - & $\otimes$ \\
\hline $\mathrm{Ni}$ & $<0.006$ & - & - & - & - & $\theta$ \\
\hline Mo & 0.002 & - & - & - & - & $\theta$ \\
\hline V & $<0.025$ & - & - & - & - & $\otimes$ \\
\hline $\mathrm{Ag}$ & $<0.010$ & - & - & - & - & - \\
\hline $\mathrm{Sb}$ & - & - & - & - & - & $\theta$ \\
\hline $\mathrm{Bi}$ & - & - & - & - & - & $\theta$ \\
\hline $\mathrm{Ge}$ & - & - & - & - & - & $\theta$ \\
\hline $\mathrm{Pb}$ & - & - & - & - & - & $\otimes$ \\
\hline Sn & - & - & - & - & - & $\theta$ \\
\hline $\mathrm{Ti}$ & - & & - & - & - & $\otimes$ \\
\hline
\end{tabular}

higher $\mathrm{Cl}$ values of the groundwater, these would effectively mask any changes in $\mathrm{Cl}$ brought about by rainfall. As was pointed out by Bredenkamp (2000), this method is particularly applicable to dolomitic aquifers where the $\mathrm{Cl}$ values are low and any increases or decreases in $\mathrm{Cl}$ would be easily detectable.

In considering problems experienced with the copious amount 


\begin{tabular}{|c|c|c|c|c|c|c|}
\hline \multicolumn{7}{|c|}{ TABLE 4 (continued) } \\
\hline & RD-1999 & RD-1988 & $\begin{array}{c}\text { M\&V- } \\
1983\end{array}$ & $\begin{array}{r}\text { GP-1970 } \\
\text { Water }\end{array}$ & MR-1915 & $\begin{array}{r}\text { GP-1970 } \\
\text { Sand }\end{array}$ \\
\hline $\begin{array}{l}\text { GASES \% }(\mathrm{F}=\mathrm{mg} / \mathrm{l}) \\
\text { Oxygen } \\
\text { Carbon dioxide } \\
\text { Sufurated hydrogen } \\
\text { Hydrogen } \\
\text { Nitrogen } \\
\text { Methane }\end{array}$ & $\begin{array}{l}- \\
- \\
- \\
- \\
- \\
-\end{array}$ & $\begin{array}{l}- \\
- \\
- \\
- \\
- \\
-\end{array}$ & $\begin{array}{l}- \\
- \\
- \\
- \\
- \\
-\end{array}$ & $\begin{array}{r}3.6 \\
- \\
- \\
0.0 \\
27.4 \\
6.9\end{array}$ & $\begin{array}{l}\text { F0.615 } \\
\text { F3.241 } \\
\text { F0.275 } \\
10.000 \\
18.500 \\
71.500\end{array}$ & $\begin{array}{l}- \\
- \\
- \\
- \\
- \\
-\end{array}$ \\
\hline $\begin{array}{l}\text { STABLE AND } \\
\text { RADIOACTIVE ISOTOPES } \\
\text { Hydrogen } \mathrm{dD}(\%) \\
\text { Oxygen } \mathrm{dD}^{18} \mathrm{O}(\%) \\
\text { Tritium }(\mathrm{TU}) \\
{ }^{14} \mathrm{C}(\mathrm{pmC}) \\
{ }^{13} \mathrm{C}(\%)\end{array}$ & $\begin{array}{l}- \\
- \\
- \\
- \\
-\end{array}$ & $\begin{array}{l}- \\
- \\
- \\
- \\
-\end{array}$ & $\begin{array}{r}-36.50 \\
-6.82 \\
0.30 \\
0.00 \\
0.00\end{array}$ & $\begin{array}{l}- \\
- \\
- \\
- \\
-\end{array}$ & $\begin{array}{l}- \\
- \\
- \\
- \\
-\end{array}$ & $\begin{array}{l}- \\
- \\
- \\
-\end{array}$ \\
\hline $\begin{array}{l}\text { OTHER } \\
\text { Sodium chloride }(\mathrm{NaCl}) \\
\text { Sodium nitrate }\left(\mathrm{NaNO}_{3}\right) \\
\text { Ammonium bicarbonate }\left(\mathrm{NH}_{4} \mathrm{HCO}_{3}\right) \\
\text { Lithium chloride }(\mathrm{LiCl}) \\
\text { Calcium chloride }\left(\mathrm{CaCl}_{2}\right) \\
\text { Calcium sulfate }\left(\mathrm{CaSO}_{4}\right) \\
\text { Calcium bicarbonate } \mathrm{Ca}\left(\mathrm{HCO}_{3}\right)_{2} \\
\text { Magnesium chloride }\left(\mathrm{MgCl}_{2}\right) \\
\text { Barium sulfate }\left(\mathrm{BaSO}_{4}\right) \\
\text { Ferrous bicarbonate } \mathrm{Fe}\left(\mathrm{HCO}_{3}\right)_{2} \\
\text { Aluminum oxide }\left(\mathrm{Al}_{2} \mathrm{O}_{3}\right)\end{array}$ & $\begin{array}{l}- \\
- \\
- \\
- \\
- \\
- \\
- \\
- \\
- \\
-\end{array}$ & $\begin{array}{l}- \\
- \\
- \\
- \\
- \\
- \\
- \\
- \\
- \\
-\end{array}$ & $\begin{array}{l}- \\
- \\
- \\
- \\
- \\
- \\
- \\
- \\
- \\
-\end{array}$ & $\begin{array}{l}- \\
- \\
- \\
- \\
- \\
- \\
- \\
- \\
- \\
-\end{array}$ & $\begin{array}{r}1890.815 \\
0.521 \\
2.730 \\
4.202 \\
242.233 \\
2.499 \\
21.060 \\
3.109 \\
1.256 \\
1.064 \\
1.610\end{array}$ & $\begin{array}{l}- \\
- \\
- \\
- \\
- \\
- \\
- \\
- \\
- \\
-\end{array}$ \\
\hline $\begin{array}{ll}* & \text { Based on the salinity of sea water } \\
\otimes & \text { Minerals occurring in the sands }\end{array}$ & $5000 \mathrm{mg} / \mathrm{l}$ & $\begin{array}{cc}* * & \text { Bas } \\
& \varnothing\end{array}$ & $\begin{array}{l}\text { ne } \mathrm{NaCl} \text { o } \\
\text { als tested }\end{array}$ & $\begin{array}{l}\text { a water }=29 \\
\text { but not foun }\end{array}$ & $\begin{array}{l}0 \mathrm{mg} / \mathrm{l} \\
\text { the sands }\end{array}$ & \\
\hline
\end{tabular}

of groundwater during the various excavations, and the amount of water issuing from the spring eyes, drilling results have indicated that the occurrence of groundwater in the immediate area may not be as plentiful as might be expected. From Fourie's (1970) tables it was deduced that four out of eleven boreholes were dry up to a depth of $34 \mathrm{~m}$, that six of the holes produced slightly saline water, and that only one bore hole produced very saline water. This would somewhat contradict Grobler and Loock (1988) who stated that the whole area had a high water table from which the water emanates. This is presumably a reference to problems with the groundwater flow in the earlier excavations. From the literature it would also appear that two auger drilling programmes have been carried out at Florisbad. The first must have been prior to Fourie's (1970) study, and the second in 1981 (Rubidge and Brink, 1985). Unfortunately there has been no attempt to correlate and examine data from these two programmes in the light of the bed-rock profile and water table.

The water table in the immediate area of the spring is effectively represented by the level of the groundwater in the exploration pits, and is supported by Brink's (1987) statement that earlier excavations were at times carried out below the water table. Due to human influences over the years, such as the construction of the swimming pools, which included discharge pipes, it is difficult to denote an accurate level to the spring eye. Fourie (1970) recorded two large and seven small eyes in the indoor pool, two large and seven small eyes in the first outdoor pool, and one large and three small eyes in the second outdoor pool. For the purpose of this study the zero level of the spring eye has been taken as the level of the water in the indoor pool. The depth of the overburden and depth to the water table, as given in the literature is often of little value because the exact locality of where the measurements were taken are not known. In 1982, Butzer (1984) put the water table at $1.7 \mathrm{~m}$ above the basement and about $390 \mathrm{~mm}$ below Peat II.

Taking the indoor pool spring eyes as zero, the water table in $\mathrm{P} 1$ was $200 \mathrm{~mm}$ higher than the spring-water; in P2, $300 \mathrm{~mm}$ higher; and in P3, $500 \mathrm{~mm}$ higher. In P4 the water table was $450 \mathrm{~mm}$ lower than the spring-water. This was an indication that the water table was at a fairly even level over most of the area, rising slightly to the north and east, and then dropping to the south. It will be noted from the contours in Fig. 1 that it is only between P3 and P4 that there is any real correlation between the water table and the topography. The water table would therefore appear to correspond more to the bedrock profile, rather than the topography. As the water table is currently almost level with the top of Peat II in pits P2 and P3, in relation to Butzer's (1984) observations, the water table is now approximately $650 \mathrm{~mm}$ higher than in 1982 . The pre-1982 average ten-year rainfall, which was $524 \mathrm{~mm}$, was higher than either the pre-1988 or pre-1999 ten-year average rainfall, may be yet another indication that long-term rainfall has little influence of the level of the water table. Bredenkamp (2000) stated that groundwater level was linearly related to average rainfall over a number of preceding years. 
It could well be expected that, in an area of less than $1000 \mathrm{~m}^{2}$, that the TDS of the groundwater would be relatively uniform particularly if there was any influence from the stable spring-water. With variations of up to $666 \%$ between P199 and P499 it appeared that some other factor(s) might be involved, and the possible effect of evaporation from the pits, coupled with an associated concentration of ions, was considered. Evaporation from P299 and P399 was not thought to be a factor as P299 was a narrow excavation, $6.70 \mathrm{~m}$ deep, and largely protected from influences such as wind and extended periods of direct sunlight, although some evaporation would have still taken place. While P399 was shallower at $4.20 \mathrm{~m}$, it was shaded by very large eucalyptus trees, and covered with iron sheeting just above the water table.

A siphoning effect from the eucalyptus trees was considered a possibility. The groundwater TDS increase between P299, P399 and P499 was, however, almost lineal with no anomaly evident at P399. The number of individual ion concentration increases and decreases between these pits also remained constant (Fig. 2). This would tend to indicate that the trees did not exert any undue influence on the groundwater TDS. Pit P499, with its high TDS, was shallower at $2.95 \mathrm{~m}$, and the sides of the pit had eroded to form a very exposed, open basin-shaped excavation. This pit was directly exposed to the sun for long periods of time, but there was no influence from large trees. Evaporation, as a cause of the high values in P499 appeared to be a distinct possibility. However, the water table in P199, in the main excavation area, was even shallower at $450 \mathrm{~mm}$, with erosion again having resulted in a very exposed open basin-shaped excavation. Although this was the most exposed of all the pits, contrary to P499, the TDS in P199 was the lowest of the four pits. Based on these considerations it was felt that neither evaporation nor a siphoning effect from the trees were factors in influencing the TDS of the groundwater in the pits.

The higher $\mathrm{SO}_{4}$ and $\mathrm{Cl}$ values in the groundwater of a rural environment such as Florisbad could possibly be interpreted as an indication of pollution. However, Fig. 2 , in conjunction with Table 1 , shows that ion increases were not confined to $\mathrm{SO}_{4}$ and $\mathrm{Cl}$ alone. Between $41 \%$ and $53 \%$ of ions showed an increase in their individual concentrations between the pits from west to east. The springs at Florisbad were closed to the public in April 1980 when they were handed over to the National Museum for research purposes. Therefore, for the past 20 years the influence and effect of rural activities on pollution has been minimal, with a permanent manager and visiting researchers being the only residents. The toilets in the change-room near $\mathrm{P} 3$ and $\mathrm{P} 4$ were seldom, if ever, used during the first 10 years of occupation by the National Museum, and have been out of order for the remaining period. Sewage from the residence drains to the north away from the exploration pits. The large number of groundwater ion concentration increases, which cannot all be related to possible pollution, coupled with the $\mathrm{SO}_{4}$ values being so much lower than the $\mathrm{Cl}$ values, would tend to suggest that pollution has had little influence and that some other factor or mechanism might be responsible for the higher pit-water values. The apparent spring-water $\mathrm{SO}_{4}$ increase between 1915 and 1983 (Table 4) is also disproportionately higher than the $\mathrm{Cl}$ increases and not thought of as being pollution-related. Along with the high $1983 \mathrm{~F}$ value, the importance of regular water monitoring is emphasised as a tool in confirming or disproving such anomalies.

Based on the water and rainfall analyses it was concluded that there was a definite association between the groundwater ion values and short-term rainfall. The pronounced influence of shortterm rainfall may partially be due to the shallow nature of the site, bed-rock-wise, as well as the porosity of the aeolian sand. However in the Florisbad context, the results of this study were contrary to the originally proposed theory that high recharge would dilute groundwater concentrations, as well as being contrary to that of established theories. Established theories state that if TDS of groundwater were low, this was an indication of a high rate of groundwater renewal, while conversely, if the groundwater TDS were high, then the rate of groundwater renewal was low (Bredenkamp, 2000). This theory is also applicable to surface waters (Kruger and Lubczenko, 1994) with the latter two statements both supporting the original theory. However, the results at Florisbad clearly showed that during periods of high recharge the TDS of the groundwater in P1 was higher, and conversely, during periods of low recharge the TDS of the groundwater in P1 was lower. These results were not only in relation to $\mathrm{P} 1$, but also in relation to $\mathrm{P} 1$ and the spring-water. Why the Florisbad results should be contrary to what appears to be the norm is not known at this stage, but it could indicate that there are some other factors or mechanisms involved. This is also the subject of ongoing investigations.

Results have indicated that long-term rainfall probably has little effect on the ion values in the groundwater. However, longterm effects would be more difficult to evaluate as long-term rainfall would dissipate with the groundwater over a relatively short period, and unless an accumulation effect could be determined, any effects of long-term rainfall would be smoothed out by shorterterm rainfall. The effects of long-term rainfall on the spring-water would be difficult to determine at this stage. Besides the intake area of the aquifer and the flow of the spring being unknown, the travel time for recharge to travel through the aquifer to the spring eyes, is also unknown. In any event, the travel time of water from the intake to the spring eyes would be considerably longer than the ten-year period examined here.

The spatial variability of rainfall through characteristic isolated storms in semi-arid areas could detract from using rainfall figures from distant monitoring sites as data in analytical methods. A comparison of rainfall figures for a 62-year period between Florisbad and Glen Agricultural College, $32 \mathrm{~km}$ south-east of Florisbad, showed that the rainfall average was $15 \%$ higher at Glen (Douglas, 1992). Bredenkamp (2000) noted that monitoring at the Grootfontein aquifer implied that variability in monthly rainfall was largely homogenised in spite of a large variability in daily rainfall. Despite considerable variations in previously mentioned annual rainfall at Florisbad, variability in annual rainfall will also be homogenised over the long term as illustrated by the 78 year average of $496 \mathrm{~mm}$ in relation to the $500 \mathrm{~mm}$ isohyet. Although this homogenisation of rainfall results may well be applicable to monthly and annual rainfall, Bredenkamp (2000) still felt that there was an uncertainty and unreliability associated with the use of records from remote monitoring points.

In relation to the large herds of animals that previously roamed the area, the potability of the Florisbad spring-water in relation to quality is of some importance. Smit (1977), for example, noted that Kalahari animals could tolerate water with a TDS of $6000 \mathrm{mg} / \mathrm{l}$. Kruger and Lubczenko (1994) give the salinity tolerance (approximate to TDS) of drinking water for pigs and milking cows as $<3200 \mathrm{mg} / \mathrm{l}$; dry dairy cows and horses $<4500 \mathrm{mg} / \mathrm{l}$; beef cattle $<5760 \mathrm{mg} / \mathrm{l}$, and sheep $6400 \mathrm{mg} / \mathrm{l}$. Although the Florisbad springwater is the most saline of South African spring-waters (2 378 $\mathrm{mg} / \mathrm{l}$ TDS), the above tolerances would clearly indicate that the spring-water is actually relatively sweet and potable for most animals. In contrast to the salinity of spring-water, after the heavy 1988 rains, water in the salt pan just north-west of Florisbad, registered a TDS of $10346 \mathrm{mg} / \mathrm{l}$, representing a salinity of $29.56 \%$ of sea water (Douglas, 1992). This was the first time in living memory that this much water had accumulated in the pan, and at these levels the Florisbad spring-water would have been far more attractive to the herds of game. Seaman et al. (1991) recorded 197 
$295 \mathrm{mg} / \mathrm{l} \mathrm{TDS}$ for the salt pan, or $564 \%$ the salinity of sea water, and an $\mathrm{NaCl}$ content of $188000 \mathrm{mg} / \mathrm{l}$. These concentrations are approaching that of the Dead Sea with a TDS of $250000 \mathrm{mg} / \mathrm{l}$. As no precise locality was given for these samples, the values could possibly only have been obtained if they were taken directly from one of the very saline boreholes supplying the evaporative salt dams, or from one of the evaporation dams itself.

It was postulated by both Fourie (1970) and Butzer (1988) that the saline nature of the spring-water, combined with the steady release of methane gas, was an indication of the saline and carbonaceous facies of the underlying Ecca shale. Coal and carbon bearing layers in the Ecca shale were also given as a possible source of methane gas by Fourie (1970). Grobler and Loock (1998) felt that the Ecca shale was deposited under marine conditions with abundant concretions, many of which had a core of organic material and some pyrite, and that these were possibly the origins of the methane gas. Both Rindl (1916) and Fourie (1970) suggested that the carbonaceous turf and peat layers at Florisbad may also have contributed to the production of methane gas. This theory was however discounted by Brink (1987), who stated that gas had been observed emanating from bedrock during test excavations. Other probable reasons for discounting the possibility of the methane gas being associated with the peat beds are, the clarity of the springwater and the shallow depth of the bed rock, which would not allow for any significantly thick layers of organic matter in the immediate vicinity of the spring.

Mazor and Verhagen (1983) did not record any of the carbon isotopes ${ }^{14} \mathrm{C}$ and ${ }^{13} \mathrm{C}$, and stated that the tritium value of $0.3 \mathrm{TU}$ could effectively be regarded as zero. Florisbad was not included in the study by Mazor and Verhagen (1983) on the stable hydrogen and oxygen isotopic composition of adjacent rivers. Results however indicated that the springs examined by Mazor and Verhagen (1983) were recharged either by direct rain infiltration, or were recharged during a possibly cooler climatic period with isotopically lighter rains. Mazor and Verhagen (1983) concluded that all the springs they examined were of meteoric origin and that temperatures, salinity, and stable oxygen and hydrogen isotopic composition showed no correlation with radiocarbon age. It can therefore be presumed that this may be applicable to Florisbad as well and that radiocarbon dating of the water would not be an effective method of dating.

It is apparent from the results presented here, and the review of previous investigations, that there are many areas where further research is required in order to obtain a better understanding of the hydrological environment at Florisbad. For example, there is still a lack of understanding regarding the relationship between rainfall and water quality. The application of the cumulative rainfall departure technique (CRD), as given by Bredenkamp (2000), may provide more information on many aspects of the spring. Explanations to questions such as, why there is such a considerable difference between the water quality of the groundwater over such short distances, why high recharge is resulting in high TDS values when this appears to be contrary to the norm, and what are the possible origins of the high mineral content of the groundwater, are currently under investigation.

\section{Acknowledgements}

I would like to thank the following persons at the National Museum, Bloemfontein: the Directors and the Board of the National Museum for giving me the opportunity to temporarily diverge with this project: JS Brink and Mrs Z Henderson for co-operation with field work as well as discussions and comments on aspects of the project. The efforts of the two referees and the Editor, whose constructive comments have helped considerably in broadening the scope of this paper, as well as improving it, are also acknowledged.

\section{References}

ANON (1980) Florisbad wetenskaplike vindplek by uitnemendheid. Nas. Mus. News 19 1-13.

BREDENKAMPDB (2000) Groundwater Monitoring: A Critical Evaluation of Groundwater Monitoring in Water Resources Evaluation and Management. Water Research Commission Report No 838/1/00.

BRINK JS (1987) The archaeozoology of Florisbad, Orange Free State. Mem. Nas. Mus. Bloemfontein 24 1-151.

BRINK JS (1988) The taphonomy and palaeoecology of the Florisbad spring fauna. Palaeoecol. of Afr. 19 169-179.

BROUWER A (1967) General Palaeontology. Oliver and Boyd, Edinburgh and London.

BUTZER KW (1984) Archeological and quaternary environment in the interior of southern Africa. In: RG Klein (ed.) Southern African Prehistory and Paleoenvironments. AA Balkema, Rotterdam. 1-64.

BUTZER KW (1988) Sedimentological interpretation of the Florisbad spring deposit. Palaeoecol. of Africa 19 181-189.

DOUGLAS R M (1992) Investigations Into the Ecology of the Herpetofauna of Florisbad Research Station, Orange Free State, South Africa. Unpublished M.Sc. Thesis, Dept. of Biol., Univ. of Natal, Durban.

DREYER TF (1938) The archaeology of the Florisbad deposits. Argeol. Navors. Nas. Mus. Bloemfontein. 1 65-77.

FORD WE (1966) A Textbook of Mineralogy (4th edn.). John Wiley \& Sons Inc. New York, London, Sydney.

FOURIE GP (1970) Die Geologie van Florisbad. Unpublished Report D- 0144: Geol. Surv. S. Afr. 1-50

GROBLER NJ and LOOCK JC (1988) The Florisbad mineral spring: Its characteristics and genesis. Navors. Nas. Mus., Bloemfontein. 5 473485.

JOUBERT A and VISSER JNJ (1991) Approximate age of the thermal spring and lacustrine deposits at Florisbad, Orange Free State. Navors. Nas. Mus. Bloemfontein 7 97-111.

KENT LE (1948) Die Geneeskragtige Bronne van Suid-Afrika. Publicity and TravelDepartment, S.A.R.\&H., ProEcclesia Printers, Stellenbosch.

KENT LE (1949) The thermal waters of the Union of South Africa and South West Africa. Geol. Soc. S. Afr. 52 231-264.

KUMAN K, INBAR M and CLARKE RJ (1999) Palaeoenvironments and cultural sequence of the Florisbad Stone Age hominid site, South Africa. J. Archaeol. Sci. 26 1409-1425.

KRUGER T and LUBCZENKO V (1994) A Community Water Quality Monitoring Manual for Victoria. Victorian Community Water Quality Monitoring Task Group, Victoria.

LOOCK JC and GROBLER NJ (1988) The regional geology of Florisbad. Navors. Nas. Mus. Bloemfontein 5 489-497.

MAZOR E and VERHAGEN BTh (1983) Dissolved ions, stable and radioactive isotopes and noble gases in thermal waters of South Africa. J. Hydrol. 63 315-329.

RINDL MM (1915) The mineral spring on the farm Rietfontein, district Brandfort, OFS. S. Afr. J. Sci. 12 561-588.

RINDL MM (1916) The medicinal springs of South Africa. S. Afr. J. Sci. 13 528-552.

RUBIDGE BS and BRINK JS (1985) Preliminary survey of the extent and nature of the pleistocene sedimentary deposits at Florisbad, South Africa. Navors. Nas. Mus. Bloemfontein 5 69-76.

SEAMAN MT, ASHTON PJ and WILLIAMS WD (1991) Inland salt waters of southern Africa. Hydrobiol. 210 75-91.

SMIT PJ (1977) Die Geohidrologie in die Opvangsgebied van die Moloporivier in die Noordelike Kalahari. Unpublished Ph.D. Thesis, Univ. of the Orange Free State, Bloemfontein.

VISSER JNJ and JOUBERT A (1991) Cyclicity in the Late Pleistocene to Holocene spring and lacustrine deposits at Florisbad, Orange Free State. S. Afr. J. Geol. 94 123-131. 